\title{
Organizational Rumor Scale for Educational Institutions
}

\author{
Abidin Dağli ${ }^{1}$, Bünyamin Han ${ }^{2, *}$ \\ ${ }^{1}$ Dr., Department of Educational Sciences, Faculty of Education, Dicle University, Turkey \\ ${ }^{2}$ Res. Ast., Department of Educational Sciences, Faculty of Education, Dicle University, Turkey
}

Copyright $\bigcirc 2018$ by authors, all rights reserved. Authors agree that this article remains permanently open access under the terms of the Creative Commons Attribution License 4.0 International License

\begin{abstract}
The aim of this research is to develop an "Organizational Rumor Scale" for educational organizations based on teachers' views on organizational rumors. In accordance with the scale development phases, first, the literature was reviewed and theoretical information was itemized, and then the items were revised based on the opinions of experts in the field of educational sciences and the opinions of the teachers. The final 24-item scale form was applied to a study group consisting of 322 teachers working in 25 primary schools in the city center of Diyarbakır, Turkey. The data were analyzed by statistical analysis. For the validity and reliability analyzes, anti-image correlation matrix, item total correlation, explanatory factor analysis, reliability analysis of internal consistency, correlation between dimensions and confirmatory factor analysis were performed. The values in the findings of the scale are within the acceptable limits and competent according to the criteria accepted in the literature. Taking into account the validity and reliability analysis of the scale, it has been decided that the "Organizational Rumor Scale" is a valid and reliable scale to evaluate the organizational rumors in schools. The scale consists of three dimensions (getting information, socialization and cynic effect) and a total of 24 items.
\end{abstract}

Keywords Scale Development, Rumor, Informal Communication

\section{Introduction}

The fulfillment of social necessities and the need of solving social problems lead human beings to work together with other community members. As natural consequence of this enforcement, organizations emerge in society [1]. Organizations established to fulfill specific objectives need to have an effective management understanding so that they can achieve these goals. Organization management is a whole and has some processes. In terms of educational organizations these processes can be categorized as decision making, planning, organizing, communication, coordination, impact and evaluation $[2,3,4]$. These processes need to be managed effectively for a successful management of an organization. Communication, one of these processes, is an effective key element in effective organizational management.

Communication is defined as the process of sharing certain feelings, thoughts and information between two or more people, and making the meanings common [2]. It is possible to talk about various forms of organizational communication. Communication in organizations is characterized by formal and informal communication channels. Formal communication channels are bounded and structured in accordance with certain rules and informal communication channels arise from interpersonal relationships and not included in any communication structure [5]. Formal communication is provided with the highest hierarchy within the organization and with other members or people outside the institution (internal notes, reports, meetings, written proposal reports, oral presentations, interviews, speeches, press bulletins, press conferences, etc.). Informal communication forms are gossip and rumor, etc. which are not in the hierarchical structure of the institution [6]. The rumor and gossip, called the oldest media in the world, are within the informal dimension of the communication process [7]. Therefore, rumor and gossips among the people in the organizations are considered to be very important in organizational researches because they constitute a large part of the communication among people.

Rumor, is defined as unconfirmed news, narrations, and stories circulating in a community or social cluster in the sense that a certain event has happened [8]. Moreover rumors are defined as unverified and instrumentally relevant information statements in circulation that arise in contexts of ambiguity, danger, or potential threat and that function to help people make sense and manage risk [9].

Rumors have a very long history and are known as a very effective mass communication channel [10]. It is surprising 
that rumors have not been adequately examined in management and organizational studies while they have a potential to disrupt the harmony of organizations if not well-directed [11]. A baseless rumor may be the most harmful attack that an organization or company may encounter. A rumor can prevent the organization to function properly. In the slightest form, managers will have to spend a lot of time deciding whether or not to fight against it or how to fight it. This will waste the time which is most precious for the organization [12]. Therefore the organizational rumors which are so important for organizational managers, need to be carefully investigated by organizational researchers.

The informal networks in which rumors are spread serve a number of purposes that can be useful in any organizational environment when properly managed. Therefore, rumors are categorized as positive and negative in the literature. Rumors are mostly thought to be harmful for the functioning of the organization. Managers perceive rumors as behaviors that must be reduced or destroyed within the organization [13].

It is possible to talk about the beneficial and harmful effects of the rumors on organizations. The rumors can function as a satisfactory element and a source of support for those in the organizations [14] and can be used as a rapid communication source within the institution [15]. Rumors make employees feel good about them, give high morale, provide socialization in the organization, guide the group norms, and be an expression of employees' problems [15].

Although rumors are accepted as unapproved behavior by the society, they are often used in organizational communication. Despite individuals' disapprove, exhibiting such behaviors result from multifaceted and complex reasons. So, the rumors do not come out without any reason in organizations. That means there is a context that reveals them. In the literature, the factors that cause rumor in organizations are as follows; lack of information on the issues that employees need, lacks or obstacles in formal communication channels, uncertainty about the employees' concerns, fear and anxiety of the employees in the organization, the importance of the event that is the subject of the rumor, organizational changes and employee disbelief regarding their organization $[9,12,16,17,18,19$, $20,21,22,23,24,25,26]$.

Since the organizational rumors emerge to meet many different needs people, they also have some functions in organizations [22]. In this sense, rumors serve many organizational goals [9]. The rumor among a group can significantly change the outcome of the group members' collective actions [27]. In this respect, the rumors have a great influence on attitude [28]. Therefore, are not just leisure activities but having multidimensional effects on organizations [20].

When the rumor literature is taken into account, the organizational functions of the rumors are as follows; getting the information that employees need $[11,19,22$, 26], employees struggle to find truth of the events happening in their environment [9, 21,22], to understand the events and situations in the organization [22, 24, 26, 29, $30,31]$ strengthen the social relations of the employees in the organization $[9,21,22,25,32,33,34]$, and the negative (cynical) effects on the organization $[9,11,12,14$, $20,22,24,35,36]$. Therefore, it is very important that the rumors with such significant effects in the functioning of the organization should be more subject to scientific researches and that the positions of the rumors in the effective organization management should be located.

The effects of the rumors among the teachers working in educational organizations and their reflection on the management of the organization are the focus of this research. In order the schools and the management function more effectively, it is necessary to systematically determine the boundaries of the rumors circulating frequently among the teachers. For this reason, there is a need for a measurement tool that reveals the organizational rumors, one of the informal communication channels, according to the teachers' views. In the literature review no measurement tool was found to measure the teachers' views towards the organizational rumors. This research will fill this gap by developing an organizational rumor scale.

\section{Materials and Methods}

This section includes the research method, study group, development of the scale, collection and analysis of the data.

\subsection{Research Method}

This research is a scale development study and includes the developmental process of the 'Organizational Rumor Scale'.

\subsection{Study Group}

The study group of this research consists of randomly selected 322 teachers working in public primary schools in city center of Diyarbakır province during the academic year of 2016-2017. $17.0 \%$ of the teachers who participated in the survey were single and $83.0 \%$ were married. In terms of gender, $54.8 \%$ is female and $45.2 \%$ is male. In terms of education, $5,0 \%$ of the teachers have college degree, $91,3 \%$ bachelor and 3, 7\% postgraduate. In terms of seniority, $8.7 \%$ are $1-5$ years, $14.2 \%$ are $6-10$ years, $57.3 \%$ are between $11-20$ years and $19.8 \%$ are 21 years and over.

\subsection{Development of the Scale}

Through literature review information about the conceptualization of the rumor and information about the 
effects of the rumors on the organizational process were itemized and an item pool consisting of 59 items was formed. After writing items on rumors, it was consulted with the 13 instructors in the field of educational sciences to review the content and scope of the items. Some items were corrected and some of them were deleted from the scale. Before the application of the measurement tool, a total of 15 teachers working in public schools assessed the intelligibility of the items, and according to their feedback some expressions in the scale items were corrected. Based on the opinions of the academicians in the educational sciences and the teachers in the application, it was concluded that the scales were sufficient in terms of language, expression, narration and scope. Thus, the "Organizational Rumor Scale" (ORS) consisting of 24 items was prepared for the first application.

The scale is a 5-likert type measurement tool. According to this; it is defined as 5: "Totally agree", 4: "Agree", 3: "Partly agree", 2: "Disagree" and 1: "Totally disagree". The participating criteria are as follows; "1.00-1.79= Totally disagree", "1.80-2.59= Disagree", "2.60-3.39= Partly agree", "3.40-4.19 = Agree", $" 4.20-5.00=$ Totally agree".

\subsection{Data Collection and Analysis}

The application of the scale was carried out with the participation of the teachers in the 25 public primary schools located in the city center of Diyarbakır. There are various criteria for the number of participants required for statistical analysis to be meaningful and for factor loads to be significant. Current views can be examined in three categories: (Number of items/number of observations) ratios, number of absolute observations and (number of expected factors/number of observations) ratios [37, 38]. For absolute observation 300 participants are accepted as "enough" in factor formations [39]. For the ratio of number of factors to the number of observations should be 11 times [40]. Based on these criteria, 322 teachers have been applied for the application of the 24-item measuring instrument. This number is suitable according to the criteria given in the literature. For the validity and reliability analyzes; anti-image correlation matrix, item total correlation, explanatory factor analysis, reliability analysis of internal consistency, correlation between dimensions and confirmatory factor analysis were performed.

\section{Findings}

In this section, findings related to the validity and reliability analysis of the data collection tool are included. In order to examine the validity of the scale firstly, exploratory factor analysis was performed, then confirmatory factor analysis to test the suitability of the model determined in the exploratory factor analysis. The Kaiser-Meyer-Olkin (KMO) results of the scale and the Bartlett's test of sphericity were examined. The KMO value is .903 and Barlett test is significance $(p<.01)$, that means the data set is suitable for factor analysis. According to the researchers [41] suggest that if the Barlett test is significant and the KMO coefficient is higher than .60 the data can be accepted as appropriate for factor analysis.

The anti-image correlation matrix is used to see if the scale items remain in factor analysis. The anti-image correlation matrix provides a criterion for determining whether each item should remain within factor analysis. The diagonal of the matrix (points intersected by the same numbered item in the row and column) indicates the corresponding items and it is desired that the values at this intersection point be greater than 0.5 . It is desirable to remove the items falling below this value from the analysis [42]. In Figure 1 below, the Anti-Image Correlation Matrix is given.

As shown in Figure 1, it was determined that the values for all of the items in the anti-image correlation matrix were over 0.5 . These values indicate that the items are acceptable.

As a result of the exploratory factor analysis, it was determined that the scale consists of 3 dimensions. After the rotated factor, the first factor of the scale consists of 8 items $(1,2,3,4,5,6,7,8)$, the second factor has 6 items $(9,10,11,12,13,14)$ and the third dimension has 10 items $(15,16,17,18,19,20,21,22,23,24)$. By examining the contents of the items in the dimensions, the first dimension is called getting information, the second dimension is called socialization and the third dimension is called cynic effect. According to this, first dimension (getting information) explains 19.3\% of the total variance, second dimension (socialization) 18.6\%, and third dimension (cynic effect) 23.2\%. The total variance explained in 3 dimensions was found to be $61.3 \%$. The results of the analysis for validity and reliability of the scale are given in Table 1. 


\begin{tabular}{|c|c|c|c|c|c|c|c|c|c|c|c|c|c|c|c|c|c|c|c|c|c|c|c|c|}
\hline & (m1) & (m2) & (m3) & (m4) & (m5) & (m6) & (m7) & (m8) & (m9) & $(\mathrm{m} 10)$ & (m11) & $(\mathrm{m} 12)$ & $(\mathrm{m} 13)$ & (m14) & $(\mathrm{m} 15)$ & (m16) & $(\mathrm{m} 17)$ & $(\mathrm{m} 18)$ & (m19) & (m20) & (m21) & $(\mathrm{m} 22)$ & (m23) & $(\mathrm{m} 24)$ \\
\hline (m1) &, $898^{\mathrm{a}}$ &,- 254 &,- 213 &,- 129 & ,082 &,- 182 &,- 030 &,- 045 & $\mid-, 076$ &,- 057 & ,046 & ,108 & ,009 &,- 032 &,- 029 &,- 017 &,- 060 &,- 016 & 127, &,- 046 &,- 043 & ,047, &,- 034 &,- 016 \\
\hline (m2) &,- 254 &, $916^{\mathrm{a}}$ &,- 194 &,- 049 &,- 082 & ,076 & ,028 &,- 124 & ,022 &,- 064 &,- 018 &,- 052 &,- 015 & ,040 & ,020 & ,096 &,- 075 &, 011 &,- 045 &,- 022 &,- 080 & ,054 &,- 005 & ,042 \\
\hline (m3) &,- 213 &,- 194 &, $879^{\mathrm{a}}$ &,- 070 &,- 056 & ,001 &,- 126 &,- 014 &,- 188 & ,287 &,- 108 &,- 050 &,- 039 &,- 035 &,- 084 &,- 123 & ,177 &,- 001 & ,081 & ,066 & ,004 &,- 090 &,- 042 & ,060 \\
\hline (m4) &,- 129 &,- 049 &,- 070 &, $933^{\mathrm{a}}$ &,- 204 &,- 205 & ,037 &,- 209 & ,020 & ,033 & ,001 & ,041 &,- 062 &,- 051 & ,012 & ,082 & ,050 &,- 037 &,- 055 &,- 045 &, 015 & ,035 &,- 042 & ,009 \\
\hline (m6) &,- 182 & ,076 & ,001 &,- 205 &,- 177 &, $920^{\mathrm{a}}$ &,- 100 &,- 334 & ,055 & ,000 &,- 120 &,- 002 & ,034 &,- 011 & ,001 & ,045 &,- 070 & ,059 & ,005 &,- 044 & ,045 & ,026 & ,023 &,- 054 \\
\hline (m7) &,- 030 & ,028 &,- 126 & ,037 &,- 177 &,- 100 &, $927^{\mathrm{a}}$ &,- 348 &,- 001 &,- 087 &,- 024 & ,010 &,- 019 &,- 023 & ,015 & ,054 &,- 070 &,- 042 &,- 070 & ,079 & ,059 &,- 056 &,- 051 & , 107 \\
\hline (m8) &,- 045 &,- 124 &,- 014 &,- 209 &,- 144 &,- 334 &,- 348 &, $896^{\mathrm{a}}$ &,- 069 & ,030 & ,053 &,- 111 & ,055 & ,009 &,- 047 &,- 084 & ,101 & ,044 &,- 009 & ,021 &,- 048 & ,059 & ,043 &,- 134 \\
\hline (m9) &,- 076 & ,022 &,- 188 & ,020 &,- 004 & ,055 &,- 001 &,- 069 &, $921^{\mathrm{a}}$ &,- 388 &,- 179 &,- 238 &,- 086 & ,174 & ,058 &,- 038 & ,082 &,- 057 &,- 003 &,- 045 & ,008 &, 065 &,- 045 & ,037 \\
\hline (m10) & $\mid-, 057$ &,- 064 & ,287 & ,033 &,- 078 & ,000 &,- 087 & ,030 & $\mid-, 388$ &, $895^{\mathrm{a}}$ &,- 261 &,- 007 &,- 087 &,- 369 &,- 091 &,- 044 & ,034 & ,113 & ,078 &,- 018 &,- 040 & ,006 &,- 008 & ,001 \\
\hline (m12) & , 108 &,- 052 &,- 050 & ,041 &, 043 & $\mid-, 002$ & ,010 &,- 111 &,-- 238 &,- 007 &,- 164 &, $922^{\mathrm{a}}$ &,- 309 &,- 079 & ,040 & ,090 &,- 146 &,- 055 & ,009 & ,138 &,- 087 &,- 082 &, 107 &,- 023 \\
\hline (m13) & ,009 &,- 015 &,- 039 &,- 062 &,- 024 & ,034 &,- 019 &, 055 &,- 086 &,- 087 &,- 240 &,- 309 &, $940^{\mathrm{a}}$ &,- 170 &,- 114 & 100 &,- 040 &,- 017 & ,008 & ,042 &,- 035 & ,088 &,- 052 & ,019 \\
\hline$(\mathrm{m} 14)$ &,- 032 & ,040 &,- 035 &,- 051 & ,001 &,- 011 &,- 023 & ,009 & ,174 &,- 369 &,- 205 &,- 079 &,- 170 &, $912^{\mathrm{a}}$ & ,133 &,- 154 & 139, &,- 129 & ,090 &,- 041 & ,035 &,- 063 & ,076 &,- 036 \\
\hline (m15) &,- 029 & ,020 &,- 084 & ,012 &, 000 & ,001 & ,015 &,- 047 & ,058 &,- 091 & 098, & 040 &,- 114 & 133 &, $894^{\mathrm{a}}$ &,- 396 &,- 137 &,- 077 & ,031 &,- 038 & ,104 &,- 020 &,- 057 &,- 031 \\
\hline$(\mathrm{m} 16)$ &,- 017 & ,096 &,- 123 & ,082 &, 025 & ,045 & ,054 &,- 084 &,- 038 &,- 044 &,- 013 & ,090 &, 100 &,- 154 &,- 396 &, $873^{\mathrm{a}}$ &,- 342 &,- 011 &,- 171 &,- 056 &,- 004 & ,008 &,- 003 & ,040 \\
\hline$(\mathrm{m} 17)$ &,- 060 &,- 075 & ,177 &, 050 &, 062 &,- 070 &,- 070 &, 101 & ,082 & ,034 &,- 007 &,- 146 &,- 040 & ,139 &,- 137 &,- 342 &, $908^{\mathrm{a}}$ &,- 305 &,- 011 &,- 002 &,- 060 &,- 061 & ,011 &,- 042 \\
\hline$(\mathrm{m} 18)$ &,- 016 & ,011 &,- 001 &,- 037 &,- 060 & ,059 &,- 042 & ,044 &,- 057 & ,113 & ,087 &,- 055 &,- 017 &,- 129 &,- 077 &,- 011 &,- 305 &, $890^{\mathrm{a}}$ &,- 494 &,- 021 &, 022 &,- 037 &, 050 &,- 052 \\
\hline (m19) & ,127 &,- 045 & ,081 &,- 055 &,- 037 & ,005 &,- 070 &,- 009 &,- 003 & ,078 &,- 065 & ,009 & ,008 & ,090 & ,031 &,- 171 &,- 011 &,- 494 &, $896^{\mathrm{a}}$ &,- 240 &,- 007 & ,030 &,- 235 & ,039 \\
\hline$(\mathrm{m} 20)$ &,-- 046 &,- 022 & ,066 &,- 045 &, 052 &,- 044 & ,079 & 021 &,- 045 &,- 018 &,- 051 & ,138 & ,042 &,- 041 &,- 038 &,- 056 &,- 002 &,- 021 &,- 240 &, $938^{\mathrm{a}}$ &,- 225 &,- 164 &,- 064 & ,017 \\
\hline$(\mathrm{m} 21)$ &,- 043 &,- 080 & ,004 &, 015 &,- 034 & ,045 & ,059 &,- 048 & ,008 &,- 040 & ,066 &,- 087 &,- 035 & ,035 & ,104 &,- 004 &,- 060 & ,022 &,- 007 &,- 225 &, $844^{\mathrm{a}}$ &,- 542 &,- 063 &,- 030 \\
\hline$(\mathrm{m} 23)$ &,- 034 &,- 005 &,- 042 &,- 042 &, 072 & ,023 &,- 051 &, 043 &,- 045 &,- 008 & ,011 & ,107 &,- 052 & ,076 &,- 057 &,- 003 & ,011 &, 050 &,- 235 &,- 064 &,- 063 &,- 143 &, $862^{\mathrm{a}}$ &,- 643 \\
\hline$(\mathrm{m} 24)$ &,-- 016 & ,042 & 060 & ,009, &,- 044 &,- 054 & 107, &,- 134 & ,037 & ,001 & 013, &,- 023 & ,019 &,- 036 &,- 031 & ,040, &,- 042 &,- 052 & 039, & ,017, &,- 030 &,- 101 &,- 643 &, $848^{\mathrm{a}}$ \\
\hline
\end{tabular}

Figure 1. The Anti-Image Correlation Matrix

Table 1. Results of Analysis for Validity and Reliability of the Scale

\begin{tabular}{|c|c|c|c|c|}
\hline \multicolumn{3}{|r|}{ Items } & $\begin{array}{c}\text { Item total } \\
\text { correlation }\end{array}$ & $\begin{array}{c}\text { Factor } \\
\text { Loadings }\end{array}$ \\
\hline \multirow{9}{*}{$\begin{array}{l}\text { Dimension of Getting } \\
\text { Information }\end{array}$} & 1. & $\begin{array}{l}\text { Okulumla ilgili birçok konu hakkında söylentiler yoluyla haberdar olurum. } \\
\text { I am aware of many issues related to my school through rumors. }\end{array}$ &, 589 & ,669 \\
\hline & 2. & $\begin{array}{l}\text { Okulumdaki ögrenciler hakkındaki bilgileri söylentiler yoluyla duyarım. } \\
\text { I hear some information about the students in my school through rumors. }\end{array}$ &, 530 &, 574 \\
\hline & 3. & $\begin{array}{l}\text { Okulumdaki söylenti ortamlarında arkadaşlarımdan yeni bilgiler edinirim. } \\
\text { I get new information from my friends in rumor environments in my school. }\end{array}$ &, 571 & ,604 \\
\hline & 4. & $\begin{array}{l}\text { Okul yönetiminin örtbas etmek istediği şeyleri söylentiler yoluyla duyarım. } \\
\text { Through rumors I hear what the school administration wants to cover up. }\end{array}$ & ,684 &, 783 \\
\hline & 5. & $\begin{array}{l}\text { Resmi iletişim kanallarındaki eksik bilgileri söylentiler yoluyla öğrenirim. } \\
\text { I learn missing information in the formal communication channels through } \\
\text { rumors. }\end{array}$ & ,670 &, 741 \\
\hline & 6. & $\begin{array}{l}\text { Okulumda yapılacak değişiklikleri söylentiler yoluyla önceden duyarım. } \\
\text { I hear about changes in my school in advance through rumors. }\end{array}$ & ,733 &, 802 \\
\hline & 7. & $\begin{array}{l}\text { Mesleğim ile ilgili yenilikleri ilk olarak okulumdaki söylenti ortamlarında } \\
\text { duyarım. } \\
\text { I first hear about innovations in my profession in rumor environments at my } \\
\text { school. }\end{array}$ & ,670 &, 712 \\
\hline & 8. & $\begin{array}{l}\text { Okulumdaki birçok olayın iç yüzünü söylentiler yoluyla öğrenirim. } \\
\text { Through rumors, I learn about the truth of some matters in my school. }\end{array}$ &, 787 &, 846 \\
\hline & & Cronbach-Alpha $=, 885$ & & \\
\hline \multirow{2}{*}{$\begin{array}{l}\text { Dimension of } \\
\text { Socialization }\end{array}$} & 9. & $\begin{array}{l}\text { Okulumdaki meslektaşlarımla söylentiler hakkında konuşmak sosyal ilişkilerimi } \\
\text { geliştirir. } \\
\text { Talking about rumors with my colleagues improves my social relations. }\end{array}$ & ,780 &, 762 \\
\hline & 10. & $\begin{array}{l}\text { Okulumdaki meslektaşlarımla söylentiler hakkında konuşarak can sıkıntımı } \\
\text { gideririm. }\end{array}$ &, 839 &, 829 \\
\hline
\end{tabular}




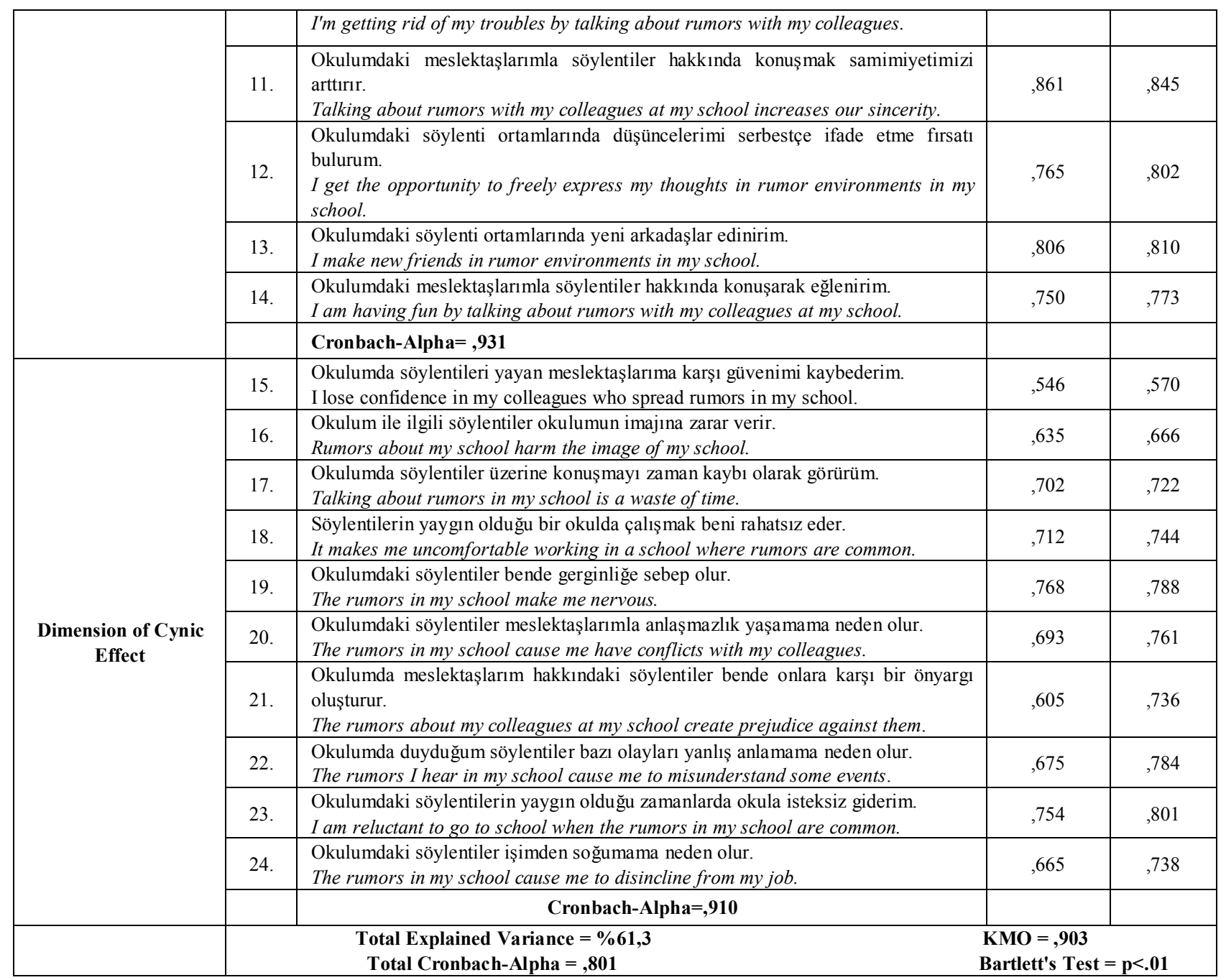

Table 1 shows that the factors loadings of the items in the first dimension ranged between .574 and .846 , the factors loadings in the second dimension ranged between .762 and .845, and the factors loadings in the third dimension ranged between .570 and .801 . The item total correlations of the items in the first dimension ranged between .530 and .787 , items in the second dimension ranged between .750 and .861 , and items in the third dimension ranged between .546 and .768. Since the factor loadings of all the items in the scale are higher than .30 , it is not necessary to remove any items from the scale.

In the correlation test to determine the relationship between the dimensions of the scale it was found moderate positive significant correlation was found between the dimensions of getting information and socialization; there is a low negative significant correlation between the dimensions of getting information and cynic effects and a moderate negative significant relationship between the dimensions of socialization and cynic effects. Table 2 shows the correlation values.

Table 2. Correlation values between the dimensions

\begin{tabular}{|c|c|c|c|c|}
\hline & & 1 & 2 & 3 \\
\hline \multirow{3}{*}{ 1. Getting Information } & Pearson Correlation & 1 &, $523^{* *}$ &,$- 183^{* *}$ \\
\hline & Sig. & &, 000 &, 001 \\
\hline & $\mathrm{N}$ & 322 & 322 & 322 \\
\hline \multirow{3}{*}{ 2. Socialization } & Pearson Correlation &, $523^{* *}$ & 1 &,$- 361^{* *}$ \\
\hline & Sig. &, 000 & &, 000 \\
\hline & $\mathrm{N}$ & 322 & 322 & 322 \\
\hline \multirow{3}{*}{ 3. Cynic Effect } & Pearson Correlation &,$- 183^{* *}$ &,$- 361^{* *}$ & 1 \\
\hline & Sig. &, 001 &, 000 & \\
\hline & $\mathrm{N}$ & 322 & 322 & 322 \\
\hline
\end{tabular}


Another method for construct validation of a measurement tool is Confirmatory Factor Analysis (CFA). The CFA process was performed to determine whether the factor structure found in the exploratory factor analysis was confirmed. The first CFA result on the model in the original form showed that the fit indexes were not at acceptable levels. Therefore it has been decided to follow the corrective steps according to the Modification Indexes. The modification shows the amount of decrease in the chi-square value with the establishment of the proposed relations. This is intended to ensure that the model fits better. It is very important that the modification proposals (the items to be interconnected) can be explained theoretically while the modification is made. Therefore, it should be taken into account that the proposed modification should be in the same dimension and that the items to be modified should be theoretically related. In addition, the modifications should be made in order starting from the proposal of the modification that will make the most improvement in the chi-square value, and the model should be retested after each modification [43, 44]. In the direction of the modification proposal, with 2 modifications in the third dimension the adaptation indexes were found to be acceptable. Figure 2 shows the CFA model and its modifications.

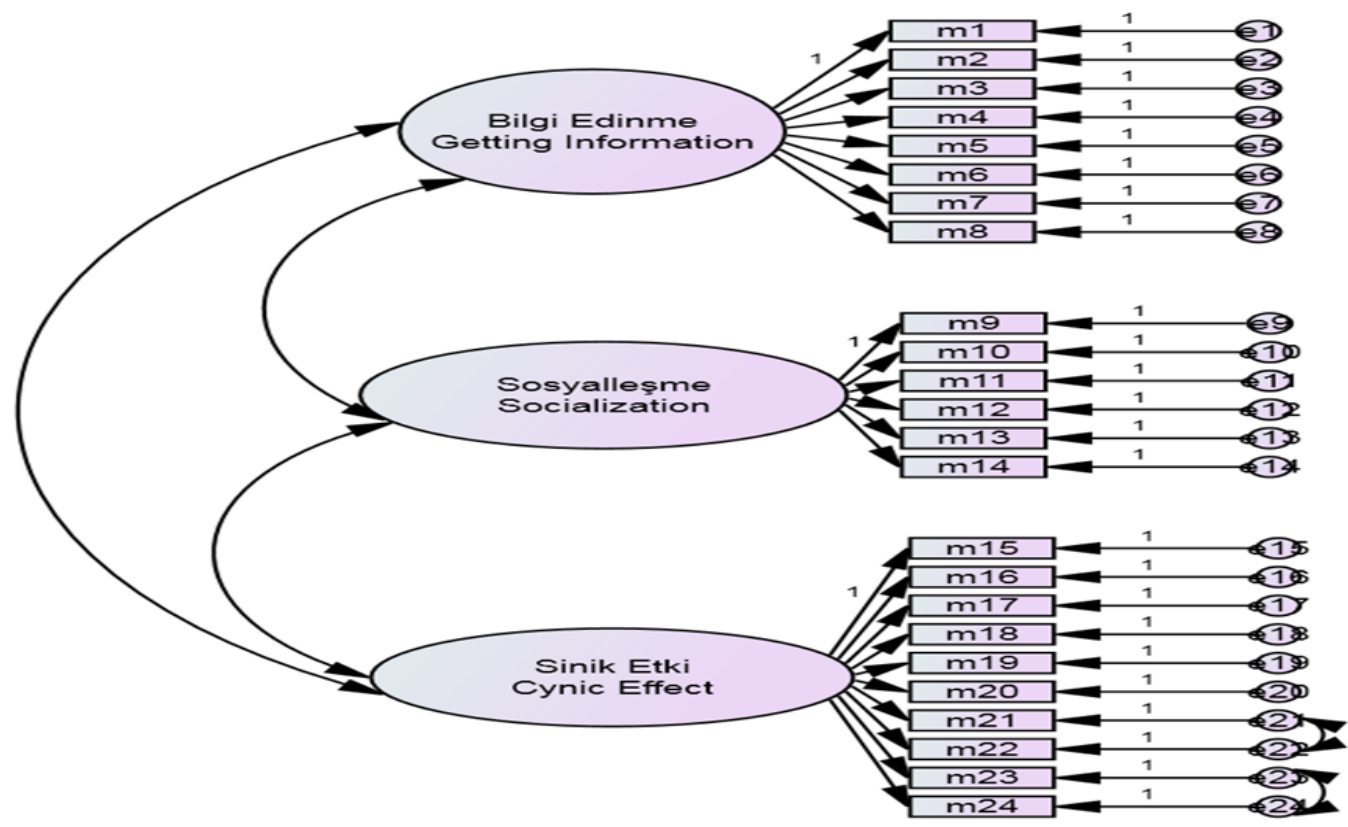

Figure 2. CFA model and its modifications

The following fit indexes which are frequently accepted as criteria in the literature are examined; Chi-Square Goodness of Fit $\chi^{2} / \mathrm{df}$, Goodness of Fit Index, GFI, Adjusted Goodness of Fit Index, AGFI, Comparative Fit Index, CFI, Normed Fit Index, NFI, Incremental Fit Index, IFI, Standardized Root Mean Square Residual, SRMR and Root Mean Square Error of Approximation, RMSEA. In Table 3, the criteria for the fit indexes determined by the researchers [45, 46, 47] and the values obtained from the CFA for the scale are given.

Table 3. Fit indexes and CFA values for the scale

\begin{tabular}{|c|c|c|c|}
\hline Fit Indexes & Good Fit Values & $\begin{array}{c}\text { Acceptable Fit } \\
\text { Values }\end{array}$ & $\begin{array}{c}\text { The } \\
\text { Scale }\end{array}$ \\
\hline$\chi^{2} / \mathrm{df}$ & $00<\chi^{2} / \mathrm{df}<2$ & $2<\chi^{2} / \mathrm{df}<3$ & 2.73 \\
\hline GFI & $0.95<\mathrm{GFI}<1.00$ & $0.90<\mathrm{GFI}<0.95$ & 0.84 \\
\hline AGFI & $0.90<\mathrm{AGFI}<1.00$ & $0.85<\mathrm{AGFI}<0.90$ & 0.81 \\
\hline CFI & $0.95<\mathrm{CFI}<1.00$ & $0.90<\mathrm{CFI}<0.95$ & 0.91 \\
\hline NFI & $0.95<\mathrm{NFI}<1.00$ & $0.90<\mathrm{NFI}<0.95$ & 0.87 \\
\hline IFI & $0.95<\mathrm{IFI}<1.00$ & $0.90<\mathrm{IFI}<0.95$ & 0.91 \\
\hline SRMR & $.00<$ SRMR $<0.05$ & $.05<\mathrm{SRMR}<0.08$ & 0.066 \\
\hline RMSEA & $.00<\mathrm{RMSEA}<.05$ & $.05<\mathrm{RMSA}<0.08$ & 0.074 \\
\hline
\end{tabular}

Table 3 shows the "good fit values ", "acceptable fit values" and "fit values of this scale" according to the various fit indexes. Although there are different ranges in terms of the criteria of fit indexes, it is seen that the values are close to each other $[43,44,48]$. The condition that the ratio of Chi-square/ degree of freedom (df) in CFA is below 3 is sought. The ratio calculated by CFA $\left(\chi^{2} / \mathrm{df}\right)$ is 2.73 and this value shows that the proposed factor model shows acceptable fit [49, 50]. For RMSEA, 0.080 is acceptable value and 0.05 is excellent fit $[51,52]$. The $\chi^{2} / \mathrm{df}$, RMSEA, SRMR, IFI and CFI values of the scale are found to be within acceptable limits. The model is always possible to be confirmed even if one or more fit indexes are outside the fit criteria [48].

On the other hand, according to some researchers [47] between 0.90-0.95 values are acceptable and 0.95 is excellent fit in values for GFI, AGFI, CFI and NFI indexes. The GFI value (0.84), AGFI value (0.81), and NFI value (0.87) in this study were close the acceptable values. According to some researchers [50] it may be due to small sample size. Moreover, some researchers [53] 
claim that the fit indexes of GFI, AGFI, NFI and RMSEA are more influenced by the sample size but CFI is less affected by the sampling size and they claim that almost all fit indexes will fit well with sample size of 1600 . For this scale the GFI value is 0.84 , the AGFI is 0.81 , and the NFI is 0.87 . According to the literature, acceptable GFI and AGFI values may be 0.90 [50], and values between $0,80-0,89$ are also as acceptable values [54, 55]. Accordingly, it was decided that these values were acceptable. In this case, it can be claimed that the CFA result confirms the model.

The reliability of the scale was tested by calculating the Cronbach's alpha internal consistency coefficient and item total correlations.

Table 4. Cronbach's Alpha Internal Consistency Coefficients Related to the Scale

\begin{tabular}{|c|c|}
\hline Dimensions & Cronbach's Alpha \\
\hline Getting Information & .885 \\
\hline Socialization & .931 \\
\hline Cynic Effect & .910 \\
\hline Total & $\mathbf{. 8 0 1}$ \\
\hline
\end{tabular}

In Table 4, the alpha internal consistency coefficient for the three-dimensional scale is .885 for the first dimension, .931 for the second dimension, and .910 for the third dimension. For the total scale, this value is .801 . Since these coefficients are over 0.70 [56, 57], it can be said that the measurements performed with the "Organizational Rumor Scale" are reliable.

\section{Results}

In this research the "Organizational Rumor Scale" was developed in order to measure the organizational rumors among the teachers based on the opinions of the classroom teachers. The items based on theoretical information were revised by taking the opinions of both experts and practitioners and then a pre-application form consisting of 24 items was created. After the application form was applied to teachers, the data were analyzed for validity and reliability. For the validity and reliability analysis of the scale; anti-image correlation matrix, exploratory factor analysis, item total correlation, internal consistency reliability analysis, inter-dimensional correlation analysis and confirmatory factor analysis were performed.

The Kaiser-Meyer-Olkin (KMO) results of the scale and the Bartlett's test of sphericity were examined. The $\mathrm{KMO}$ value is .903 and Barlett test is significance $(\mathrm{p}<.01)$, that means the data set is suitable for factor analysis. In the anti-image correlation matrix the values for all of the items were over 0.5 , which indicates that all the items are acceptable.

As a result of the exploratory factor analysis, it was determined that the scale consists of 3 dimensions. After the rotated factor, the first factor of the scale consists of 8 items $(1,2,3,4,5,6,7,8)$, the second factor has 6 items $(9,10,11,12,13,14)$ and the third dimension has 10 items $(15,16,17,18,19,20,21,22,23,24)$. By examining the contents of the items in the dimensions, the first dimension is called getting information, the second dimension is called socialization and the third dimension is called cynic effect. According to this, first dimension (getting information) explains $19.3 \%$ of the total variance, second dimension (socialization) is $18.6 \%$, and third dimension (cynic effect) is $23.2 \%$. The total variance explained in 3 dimensions was found to be $61.3 \%$. Since the factor loadings of all the items in the scale are higher than .30 , it is not necessary to remove any items from the scale.

In the correlation test to determine the relationship between the dimensions of the scale it was found moderate positive significant correlation was found between the dimensions of getting information and socialization; there is a low negative significant correlation between the dimensions of getting information and cynic effects and a moderate negative significant relationship between the dimensions of socialization and cynic effects.

The Confirmatory Factor Analysis (CFA) was performed to determine whether the factor structure found in the exploratory factor analysis was confirmed. For CFA the following fit indexes which are frequently taken as criteria in the literature are examined; Chi-Square Goodness of Fit $x^{2} / \mathrm{df}$, Goodness of Fit Index, GFI, Adjusted Goodness of Fit Index, AGFI, Comparative Fit Index, CFI, Normed Fit Index, NFI, Incremental Fit Index, IFI, Standardized Root Mean Square Residual, SRMR and Root Mean Square Error of Approximation, RMSEA. Since the values of the scale were found to be in the acceptable limits it is concluded that the model is confirmed.

The reliability of the scale was tested by calculating the Cronbach's alpha internal consistency coefficient and item total correlations. Since the coefficients of the scale are over 0.70 it can be said that the measurements performed with the "Organizational Rumor Scale" are reliable.

\section{Conclusions}

As a result of the research, a valid and reliable scale consisting of a total of 24 items and 5-Likert type rating which can be used to determine organizational rumors in schools was developed (Appendix 1).

When the findings for the validity and reliability of the "Organizational Rumor Scale" are evaluated together it can be said that the scale is a valid and reliable data collection tool that can be used to measure the organizational rumors among the teachers who work at 
schools. It can be said that the measurement tool developed in this study fill a significant deficiency in the related field and carries the feature of being a valid and reliable measurement tool which can be used in future studies.

\section{Acknowledgements}

This scale was developed in the scope of the $\mathrm{PhD}$ dissertation by Bünyamin HAN and it was presented as oral presentation at the $8^{\text {th }}$ International Education Administration Forum, Ankara, 19-21 October 2017.

\section{Appendix 1A: Original Form of "Organizational Rumor Scale" in Turkish Language}

\section{ÖRGÜTSEL SÖYLENTİ ÖLÇEĞI}

\begin{tabular}{|c|c|c|c|c|c|}
\hline & $\begin{array}{c}\text { Hiç } \\
\text { katılmıorum } \\
(1)\end{array}$ & $\begin{array}{l}\text { Katılmiyorum } \\
\text { (2) }\end{array}$ & $\begin{array}{c}\text { Kismen } \\
\text { katiliyorum } \\
\text { (3) }\end{array}$ & $\begin{array}{l}\text { Katıliyorum } \\
\text { (4) }\end{array}$ & $\begin{array}{c}\text { Tamamen } \\
\text { katilyyorum } \\
\text { (5) }\end{array}$ \\
\hline \multicolumn{6}{|c|}{$\begin{array}{ll}\text { Bilgi Edinme Boyutu } \\
\end{array}$} \\
\hline $\begin{array}{l}\text { 1. Okulumla ilgili birçok konu hakkında söylentiler } \\
\text { yoluyla haberdar olurum. }\end{array}$ & 8 & 2 & 3 & 4 & 5 \\
\hline $\begin{array}{llll}\text { 2. } & \begin{array}{l}\text { Okulumdaki öğrenciler } \\
\text { söylentiler yoluyla duyarım. }\end{array} & \text { hakkındaki } & \text { bilgileri } \\
\end{array}$ & 1 & 2 & 3 & 4 & 5 \\
\hline $\begin{array}{l}\text { Okulumdaki söylenti ortamlarında arkadaşlarımdan } \\
\text { yeni bilgiler edinirim. }\end{array}$ & 1 & 2 & 3 & 4 & 5 \\
\hline $\begin{array}{ll}\text { 4. } & \begin{array}{l}\text { Okul yönetiminin örtbas etmek istediği şeyleri } \\
\text { söylentiler yoluyla duyarım. }\end{array}\end{array}$ & 1 & 2 & 3 & 4 & 5 \\
\hline $\begin{array}{llll}\text { 5. } & \begin{array}{l}\text { Resmi iletişim kanallarındaki eksik } \\
\text { söylentiler yoluyla ögrenirim. }\end{array} & \text { bilgileri } \\
\end{array}$ & 1 & 2 & 3 & 4 & 5 \\
\hline $\begin{array}{l}\text { 6. Okulumda yapılacak değişiklikleri söylentiler yoluyla } \\
\text { önceden duyarım. }\end{array}$ & 1 & 2 & 3 & 4 & 5 \\
\hline $\begin{array}{l}\text { 7. Mesleğim ile ilgili yenilikleri ilk olarak okulumdaki } \\
\text { söylenti ortamlarında duyarım. }\end{array}$ & 1 & 2 & 3 & 4 & 5 \\
\hline $\begin{array}{ll}\text { 8. Okulumdaki birçok olayın iç yüzünü söylentiler } \\
\text { yoluyla öğrenirim. }\end{array}$ & 1 & 2 & 3 & 4 & 5 \\
\hline \multicolumn{6}{|l|}{ Sosyalleşme Boyutu } \\
\hline $\begin{array}{l}\text { 9. Okulumdaki meslektaşlarımla söylentiler hakkında } \\
\text { konuşmak sosyal ilişkilerimi geliştirir. }\end{array}$ & 1 & 2 & 3 & 4 & 5 \\
\hline $\begin{array}{l}\text { 10. Okulumdaki meslektaşlarımla söylentiler hakkında } \\
\text { konusarak can sıkıntımı gideririm. }\end{array}$ & 1 & 2 & 3 & 4 & 5 \\
\hline $\begin{array}{l}\text { 11. Okulumdaki meslektaşlarımla söylentiler hakkında } \\
\text { konuşmak samimiyetimi arttırır. }\end{array}$ & 1 & 2 & 3 & 4 & 5 \\
\hline $\begin{array}{l}\text { 12. Okulumdaki söylenti ortamlarında düşüncelerimi } \\
\text { serbestçe ifade etme firsatı bulurum. }\end{array}$ & 1 & 2 & 3 & 4 & 5 \\
\hline $\begin{array}{l}\text { 13. Okulumdaki söylenti ortamlarında yeni arkadaşlar } \\
\text { edinirim. }\end{array}$ & 1 & 2 & 3 & 4 & 5 \\
\hline $\begin{array}{l}\text { 14. Okulumdaki meslektaşlarımla söylentiler hakkında } \\
\text { konuşarak eğlenirim. }\end{array}$ & 1 & 2 & 3 & 4 & 5 \\
\hline \multicolumn{6}{|l|}{ Sinik Etki Boyutu } \\
\hline $\begin{array}{l}\text { 15. Okulumda söylentileri yayan meslektaşlarıma karşı } \\
\text { güvenimi kaybederim. }\end{array}$ & 1 & 2 & 3 & 4 & 5 \\
\hline $\begin{array}{l}\text { 16. Okulum ile ilgili söylentiler okulumun imajına zarar } \\
\text { verir. }\end{array}$ & 1 & 2 & 3 & 4 & 5 \\
\hline $\begin{array}{l}\text { 17. Okulumda söylentiler üzerine konuşmayı zaman } \\
\text { kaybı olarak görürüm. }\end{array}$ & 1 & 2 & 3 & 4 & 5 \\
\hline $\begin{array}{ll}\text { 18. } & \begin{array}{l}\text { Söylentilerin yaygin olduğu bir okulda çalışmak beni } \\
\text { rahatsız eder. }\end{array} \\
\end{array}$ & 1 & 2 & 3 & 4 & 5 \\
\hline 19. Okulumdaki söylentiler bende gerginliğe sebep olur. & 1 & 2 & 3 & 4 & 5 \\
\hline $\begin{array}{l}\text { 20. Okulumdaki söylentiler meslektaşlarımla anlaşmazlık } \\
\text { yaşamama neden olur. }\end{array}$ & 1 & 2 & 3 & 4 & 5 \\
\hline $\begin{array}{l}\text { 21. Okulumda meslektaşlarım hakkındaki söylentiler } \\
\text { bende onlara karşı önyargı oluşturur. }\end{array}$ & 1 & 2 & 3 & 4 & 5 \\
\hline $\begin{array}{l}\text { 22. Okulumda duyduğum söylentiler bazı olayları yanlış } \\
\text { anlamama neden olur. }\end{array}$ & 1 & 2 & 3 & 4 & 5 \\
\hline $\begin{array}{l}\text { 23. Okulumdaki söylentilerin yaygın olduğu zamanlarda } \\
\text { okula isteksiz giderim. }\end{array}$ & 1 & 2 & 3 & 4 & 5 \\
\hline $\begin{array}{l}\text { 24. Okulumdaki söylentiler işimden soğumama neden } \\
\text { olur. }\end{array}$ & 1 & 2 & 3 & 4 & 5 \\
\hline
\end{tabular}




\section{Appendix 1B: English Translation of "Organizational Rumor Scale"}

ORGANIZATIONAL RUMOR SCALE

\begin{tabular}{|c|c|c|c|c|c|}
\hline & $\begin{array}{c}\text { Totally } \\
\text { Disagree (1) }\end{array}$ & $\begin{array}{c}\text { Disagree } \\
\text { (2) }\end{array}$ & $\begin{array}{l}\text { Partly } \\
\text { Agree } \\
\text { (3) }\end{array}$ & $\begin{array}{c}\text { Agree } \\
\text { (4) }\end{array}$ & $\begin{array}{c}\text { Totally } \\
\text { Agree (5) }\end{array}$ \\
\hline \multicolumn{6}{|c|}{ Getting Information } \\
\hline 1. I am aware of many issues related to my school through rumors. & 1 & 2 & 3 & 4 & 5 \\
\hline $\begin{array}{l}\text { 2. I hear some information about the students in my school through } \\
\text { rumors. }\end{array}$ & 1 & 2 & 3 & 4 & 5 \\
\hline $\begin{array}{l}\text { 3. I get new information from my friends in rumor environments in } \\
\text { my school. }\end{array}$ & 1 & 2 & 3 & 4 & 5 \\
\hline $\begin{array}{l}\text { 4. Through rumors I hear what the school administration wants to } \\
\text { cover up. }\end{array}$ & 1 & 2 & 3 & 4 & 5 \\
\hline $\begin{array}{l}\text { 5. I learn missing information in the formal communication } \\
\text { channels through rumors. }\end{array}$ & 1 & 2 & 3 & 4 & 5 \\
\hline 6. I hear about changes in my school in advance through rumors. & 1 & 2 & 3 & 4 & 5 \\
\hline $\begin{array}{l}\text { 7. I first hear about innovations in my profession in rumor } \\
\text { environments at my school. }\end{array}$ & 1 & 2 & 3 & 4 & 5 \\
\hline $\begin{array}{l}\text { 8. Through rumors, I learn about the truth of some matters in my } \\
\text { school. }\end{array}$ & 1 & 2 & 3 & 4 & 5 \\
\hline \multicolumn{6}{|l|}{ Socialization } \\
\hline $\begin{array}{ll}\text { 9. Talking about rumors with my colleagues improves my social } \\
\text { relations. }\end{array}$ & 1 & 2 & 3 & 4 & 5 \\
\hline $\begin{array}{l}\text { 10. I'm getting rid of my troubles by talking about rumors with my } \\
\text { colleagues. }\end{array}$ & 1 & 2 & 3 & 4 & 5 \\
\hline $\begin{array}{l}\text { 11. Talking about rumors with my colleagues at my school increases } \\
\text { our sincerity. }\end{array}$ & 1 & 2 & 3 & 4 & 5 \\
\hline $\begin{array}{l}\text { 12. I get the opportunity to freely express my thoughts in rumor } \\
\text { environments in my school. }\end{array}$ & 1 & 2 & 3 & 4 & 5 \\
\hline 13. I make new friends in rumor environments in my school. & 1 & 2 & 3 & 4 & 5 \\
\hline $\begin{array}{l}\text { 14. I am having fun by talking about rumors with my colleagues at } \\
\text { my school. }\end{array}$ & 1 & 2 & 3 & 4 & 5 \\
\hline \multicolumn{6}{|l|}{ Cynic Effect } \\
\hline $\begin{array}{l}\text { 15. I lose confidence in my colleagues who spread rumors in my } \\
\text { school. }\end{array}$ & 1 & 2 & 3 & 4 & 5 \\
\hline 16. Rumors about my school harm the image of my school. & 1 & 2 & 3 & 4 & 5 \\
\hline 17. Talking about rumors in my school is a waste of time. & 1 & 2 & 3 & 4 & 5 \\
\hline $\begin{array}{l}\text { 18. It makes me uncomfortable working in a school where rumors } \\
\text { are common. }\end{array}$ & 1 & 2 & 3 & 4 & 5 \\
\hline 19. The rumors in my school make me nervous. & 1 & 2 & 3 & 4 & 5 \\
\hline $\begin{array}{l}\text { 20. The rumors in my school cause me have conflicts with my } \\
\text { colleagues. }\end{array}$ & 1 & 2 & 3 & 4 & 5 \\
\hline $\begin{array}{l}\text { 21. The rumors about my colleagues at my school create prejudice } \\
\text { against them. }\end{array}$ & 1 & 2 & 3 & 4 & 5 \\
\hline $\begin{array}{l}\text { 22. The rumors I hear in my school cause me to misunderstand some } \\
\text { events. }\end{array}$ & 1 & 2 & 3 & 4 & 5 \\
\hline $\begin{array}{l}\text { 23. I am reluctant to go to school when the rumors in my school are } \\
\text { common. }\end{array}$ & 1 & 2 & 3 & 4 & 5 \\
\hline 24. The rumors in my school cause me to disincline from my job. & 1 & 2 & 3 & 4 & 5 \\
\hline
\end{tabular}

Kuram ve Uygulamada Eğitim Yönetimi. (Ed. Niyazi CAN). Ankara: Pegem Akademi.

\section{REFERENCES}

[1] Başaran, İ. E. (1984). Yönetime giriş. Ankara: Ankara Üniversitesi Eğitim Bilimleri Fakültesi Yayınları.

[2] Memişoğlu, S. P. (2013). “Okulda yönetim süreçleri”.
[3] Başaran, İ. E. (1996). Eğitim yönetimi. Ankara: Yargıcı Matbaas1.

[4] Aydın, M. (2014). Eğitim yönetimi. Ankara: Pegem Akademi.

[5] Eşkin-Bacaksız, F. \& Yıldırım, A. (2013). Dedikodu ve söylenti tutumu ölçeğinin geliştirilmesi. Anadolu Hemşirelik 
ve Sağlık Bilimleri Dergisi, 2013; 16:1.

[6] Solmaz, B. (2004). Kurumsal söylenti ve dedikodu: Türkiye'deki işletmeler üzerine bir uygulama. Konya: Tablet Yayınlar1.

[7] Kniffin, K. V. \& Wilson, D. S. (2005). Utilities of gossip across organizational levels. Human Nature. Vol. 16, No. 3, pp. 278-292.

[8] TDK (2017). Türk Dil Kurumu Türkçe Sözlüğü. http://www.tdk.gov.tr.

[9] DiFonzo, N. \& Bordia, P. (2007). Rumor psychology: Social and organizational approaches. American Psychological Association, 750 First Street, NE Washington, DC.

[10] Schindler, M. (2007). Rumors in financial markets. John Wiley \& Sons Ltd, The Atrium, Southern Gate, Chichester, West Sussex PO19 8SQ, England.

[11] Michelson, G., \& Mouly, S. V. (2004). Do loose lips sink ships? The meaning, antecedents and consequences of rumor and gossip in organizations. Corporate Communications: An International Journal. 9(3), 189-201.

[12] Fearn-Banks, K. (2007). Crisis communications: A casebook approach. Lawrence Erlbaum Associates, Publishers, Mahwah, New Jersey London.

[13] Grosser, T. J., Lopez-Kidwell, V. \& Labianca, G. (2010). A social network analysis of positive and negative gossip in organizational life. Group \& Organization Management. 35(2) 177-212.

[14] Solmaz, B. (2006). Dedikodu ve söylenti yönetimi. Selçuk Üniversitesi Sosyal Bilimler Enstitüsü Dergisi, 16, 563-575.

[15] Thomas, S.A \& Rozell, E.J. (2007). Gossip and nurses: Malady or remedy? Health Care Management. 26(2):111-5.

[16] Bordia, P. \& Rosnow, R. L. (1998). Rumor rest stops on the information highway transmission patterns in a computermediated rumor chain. Human Communication Research. Vol. 25 No. 2, 163-179.

[17] Guirdham, M. (2015). Work communication: Mediated and face-to-face practices. Palgrave Macmillan.

[18] Kapferer, J. N. (1992). Dünyanın en eski medyast: Dedikodu ve söylenti. (Çev. Işın Gürbüz). İstanbul: İletişim Yayınları.

[19] Caplow, T. (1947). Rumors in war. Social Forces. Vol. 25, No. 3, pp. 298-302. http://www.jstor.org/stable/3005668

[20] DiFonzo, N., Bordia, P. \& Rosnow, R. L. (1994). Reining in rumors. Organizational Dynamics, 23, 47-62.

[21] Stewart, P. J. \& Strathern, A. (2004). Witchcraft, sorcery, rumors, and gossip. Cambridge University Press.

[22] Kimmel, A. J. (2004). Rumors and rumor control. Lawrence Erlbaum Associates, Inc.

[23] Mills, C. (2010). Experiencing gossip: The foundations for a theory of embedded organizational gossip. Group \& Organization Management. XX(X) 1-28. DOI: $10.1177 / 1059601109360392$.

[24] Brown, M. \& Napier, A. (2004). Knowledge transfer and rumor: Have we missed something? In Fifth European Conference on Organizational Knowledge, Learning and
Capabilities. Innsbruck, Austria.

http://hdl.handle.net/11072/667

URI:

[25] Fine, G. A. \& Ellis, B. (2010). The global grapevine: Why rumors of terrorism, immigration, and trade matter. Oxford University Press, Inc.

[26] Knapp, R. H. (1944). A psychology of rumor. Public Opinion Quarterly, 8(1), 22-37.

[27] Chen, H. Lu, Y. K. \& Suen, W. (2016). The power of whispers: A theory of rumor, communication and revolution. International Economic Review. Vol. 57, No. 1.

[28] Zhao, H., Lin, B. \& Guo, C. (2014). A mathematics model for quantitative analysis of demand disruption caused by rumor spreading. International Journal of Information Technology \& Decision Making. 13(03), 585-602.

[29] Rosnow, R. L. \& Foster, E. K. (2005). Rumor and gossip research. Psychological Science Agenda. 19 (4), 1-2.

[30] Bordia, P. ve DiFonzio, N. (2002). When social psychology became less social: Prasad and the history of rumor research. Asian Journal of Social Psychology. (2002) 5: 49-61

[31] Hirschhorn, L. (1983). Managing rumors during retrenchment. Advanced Management Journal, 48(3), 5-11.

[32] Guerin, B. \& Miyazaki, Y. (2006). Analyzing rumors, gossip, and urban legends through their conversational properties. Psychological Record. 56(1), 23.

[33] Dibble, J. L. \& Levine, T. R. (2010). Breaking good and bad news: Direction of the MUM effect and senders' cognitive representations of news valence. Communication Research, 37 (5), 703-722.

[34] Rosen, S. \& Tesser, A. (1970). On reluctance to communicate undesirable information: The MUM effect. Sociometry, Vol. 33, No. 3, pp. 253-263.

[35] Kieffer, C. C. (2013). Rumors and gossip as forms of bullying: Sticks and stones? Psychoanalytic Inquiry. 33: 90104.

[36] Zhao, L., Yin, J., \& Song, Y. (2016). An exploration of rumor combating behavior on social media in the context of social crises. Computers in Human Behavior. 58, 25-36.

[37] Yurdugül, H. (2005a). Davranış bilimlerinde ölçek geliştirme çalışmaları için bazı ayrıntılar. http://yunus.hacettepe.edu.tr/yurdugul ET: 27.06.2017.

[38] Yurdugül, H. (2005b). Ölçek geliştirme çalışmalarında kapsam geçerliği için kapsam geçerlik indekslerinin kullanılması. XIV. Ulusal Eğitim Bilimleri Kongresi, 1, 771-774.

[39] Comfrey, A. L. \& Lee, H. B. (1992). A first course in factor analysis. Hillsdale, NJ: Lawrence Erlbaum Associates.

[40] Osborne, J. W. \& Costello, A. B. (2004). Sample size and subject to item ratio in principal components analysis. Practical Assessment, Research \& Evaluation, 9(11).

[41] Büyüköztürk, Ş. (2002). Sosyal bilimler için veri analizi el kitabl. Ankara: Pegem Yayıncılık.

[42] Can, A. (2014). SPSS ile bilimsel araştırma sürecinde nicel veri analizi. Ankara: Pegem Akademi. 
[43] Meydan, C. H. \& Şeşen, H. (2011). Yapısal eşitlik modellemesi AMOS uygulamalart. Ankara: Detay Yayıncilık

[44] Çelik, H. E. \& Yılmaz, V. (2013). Yapısal eşitlik modellemesi temel kavramlar uygulamalar programlama. Ankara: Anı Yayıncılik.

[45] Bentler, P. M. (1980). Multivariate analysis with latent variables: Causal modeling. Annual Review of Psychology, $31(1), 419-456$.

[46] Bentler, P. M., \& Bonett, D. G. (1980). Significance tests and goodness of fit in the analysis of covariance structures. Psychological Bulletin, 88(3), 588.

[47] Hooper, D., Coughlan, J. \& Mullen, M. R. (2008). Structural equation modelling: Guidelines for determining model fit. The Electronic Journal of Business Research Methods, $6(1), 53-60$.

[48] Schermelleh-Engel, K., Moosbrugger, H., \& Müller, H. (2003). Evaluating the fit of structural equation models: Tests of significance and descriptive goodness-of-fit measures. Methods of Psychological Research Online, 8(2), 23-74.

[49] Sümer, N. (2000). Yapısal eşitlik modelleri: Temel kavramlar ve örnek uygulamalar. Türk Psikoloji Yazıları, 3 (6), 49-74.

[50] Şimşek, Ö. F. (2007). Yapısal eşitlik modellemesine giriş
(Temel ilkeler ve LISREL uygulamalart). Ankara: Ekinoks Yayınları.

[51] Byrne, B. M. \& Campbell, T. L. (1999). Cross-cultural comparisons and the presumption of equivalent measurement and theoretical structure: A look beneath the surface. Journal of Cross-Cultural Psychology, 30, 555-574.

[52] Steiger, J.H. (2007). Understanding the limitations of global fit assessment in structural equation modeling. Personality and Individual Differences, 42 (5), 893-898.

[53] Şen, R. \& Yılmaz, V. (2013). Model belirlemesi, örneklem hacmi ve tahmin yönteminin yapısal eşitlik modelleri uyum ölçütlerine etkisi. Dumlupınar Üniversitesi Sosyal Bilimler Dergisi. 38, 239-252.

[54] Segars, A. H. \&Grover, V. (1993). Re-examining perceived ease of use and usefulness: A confirmatory factor analysis. MIS Quarterly, 17 (4), 517-525.

[55] Doll, W. J., Xia, W. \& Torzadeh, G. (1994). A confirmatory factor analysis of the end-user computing satisfaction instrument. MiS Quarterly. 18 (4), 453-461

[56] Çokluk, Ö., Şekercioğlu G. \& Büyüköztürk, Ş. (2012). Sosyal bilimler için çok değişkenli istatistik: SPSS ve LISREL uygulamaları. Ankara: Pegem A Yayınları.

[57] Pallant, J. (2005). SPSS Survival manual: A step by step guide to data analysis using SPSS for windows. Australia: Australian Copyright. 